\title{
A trombosis story and PRES
}

\author{
Vural Kartal ${ }^{1}$, Zeynep Zara ${ }^{1}$, Sema Yilmaz ${ }^{2}$, Aylin Ayhan², Asim Yoruk², Cetin Timur ${ }^{2}$ \\ 1Department of Pediatrics, Istanbul Medeniyet University, Goztepe Training and Research Hospital, Istanbul, Turkey; \\ ${ }^{2}$ Department of Pediatric Hematology and Oncology, Istanbul Medeniyet University, Goztepe Training and Research \\ Hospital, Istanbul, Turkey
}

\begin{abstract}
Trombosis is seen in children with acute lymphoblastic leukemia during or after L-asparaginase treatment. Posterior reversible encephalopathy syndrome (PRES) is a complex syndrome characterized with sudden hypertension, headache, nausea, vomiting, alteration in the state of consciousness, vision defect and seizures. The cases related to this syndrome have been reportedly seen after eclampsia, organ transplantation, immunsuppressive treatments, autoimmune diseases and chemotherapy. Vasogenic edema occuring in the brain parencyhma constitues the basic pathophysiology. We present a case who developed seizures during treatment for B-cell acute lymphoblastic leukemia and diagnosed as posterior reversible encephalopathy.
\end{abstract}

Key words: Child, L-asparaginase, leukemia, PRES, thrombosis

$\mathrm{D}$ evelopment of a thrombus is a multifactorial entity. In addition to hereditary disease, as a prerequisite, a serious disease (malignancy, infection, and nephrotic syndrome etc.), acquired inhibitor deficiencies or presence of extrinsic factors such as an indwelling catheter are required [1]. In children with cancer, evidences are accumulating suggesting a clinically significant prevalence of venous thrombotic events [2] Thrombus can be seen during, and after L-asparaginase treatment of children with acute lymphoblastic leukemia [3]. Activation of primary disease by means of procoagulant substances, deterioration of fibrinolytic anticoagulant pathway, chemotherapy, and prothrombotic risk factors play a role in thrombus formation. Risk of thrombotic complication has been indicated as $1-37 \%$ in the literature [4].
Posterior reversible encephalopathy syndrome (PRES) may manifest itself with clinical symptoms as headache, visual disturbances, paresis, vomiting, seizures, and impaired conscious. Hypertensive encephalopathy, eclampsia, organ transplantation, immunosuppressive treatments, autoimmune diseases, acute glomerulonephritis, chemotherapy, and shock can induce PRES. Vasogenic cerebral edema is responsible for clinical symptoms [5]. Diagnosis is made based on clinical, and radiological findings. On magnetic resonance images (MRI) typically, hyperintensity in parietooccipital regions consistent with diffuse edema is observed. With rapid diagnosis, and treatment, the patients recover within a few weeks [6]. In order to emphasize the importance of PRES We have presented a patient who developed thrombus, and PRES during treatment of acute

Received: June 09, 2014 Accepted: July 18, 2014 Online: August 03, 2014

Correspondence: Vural KARTAL. Doktor Erkin Caddesi, Istanbul Medeniyet Üniversitesi, Göztepe Egitim ve Arastirma Hastanesi, Cocuk Sagligi ve Hastaliklari Anabilim Dalı, Kadıkoy, Istanbul, Turkey. 
lymphoblastic leukemia whose clinical, and radiological findings improved following early diagnosis, and treatment.

\section{CASE REPORT}

A swelling on the left arm of a 5-year-old girl diagnosed as common B ALL with a lower risk group who was hospitalized for an induction therapy (protocol\#: ALL IC BFM-2009) attracted our attention. Her physical examination revealed an irritable patient with a moderate health state, and an open state of consciousness. Her vital findings were within normal limits. On the examination of her left arm, red-colored skin, diffuse edema (circumferences of the left, and right arms were $28 \mathrm{~cm}$, and 17 $\mathrm{cm}$, respectively), painful, and warm skin were observed. Doppler US of the left upper extremity was reported as "stagnation of venous blood flow at the junction the left cephalic, and subclavian veins, and presence of a thrombus with a diameter of $7 \mathrm{~mm}$." Her hematological, and biochemical examination results were within normal limits. However we had not necessary facilities to perform laboratory tests so as to reveal the etiological factors of thrombus. Low-molecular weight heparin (LMWH) (enoxaparine sodium $100 \mathrm{U} / \mathrm{kg} / \mathrm{g}, \mathrm{SC}$ ) was initiated as a thrombolytic treatment. At the same night the patient experienced tonic-clonic convulsions. Her convulsions were controlled with phenobarbital (15 $\mathrm{mg} / \mathrm{kg} / \mathrm{g}, \mathrm{IV})$. Cranial computed-tomograms obtained to reveal the cause of convulsions were unremarkable. On cranial magnetic resonance (MR) venograms, no-flow phenomenon was observed within the left transverse sinus (Figure 1a, arrow). However diffusion MRI revealed the presence of blood flow inside the transverse sinuses without any thrombi. In fact contrast agent was not seen only on
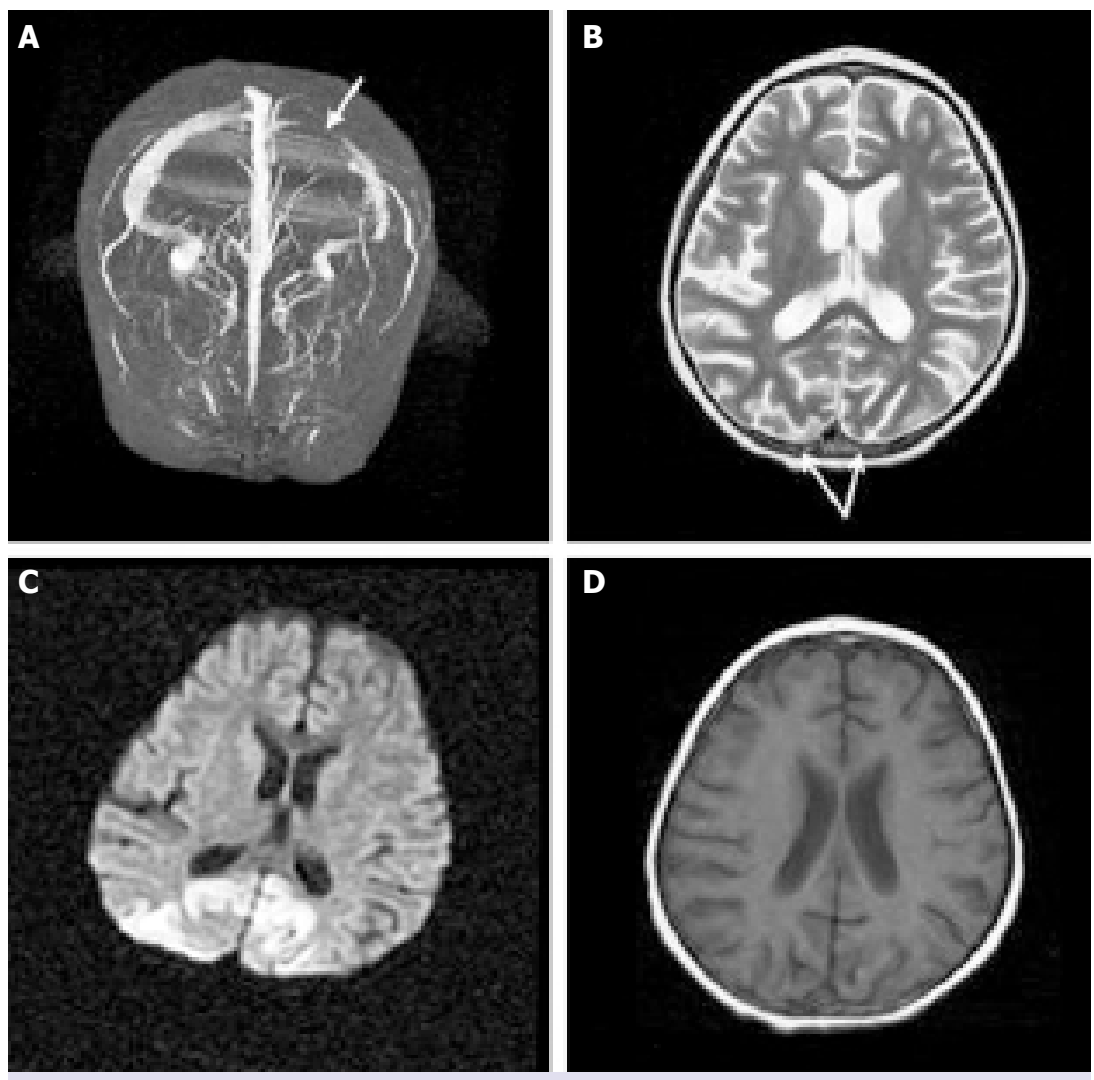

FIGURE 1. Cerebral diffusion MRI. (A) MRI venography. Left transverse sinus blood flow is not observed (arrow). (B) Blood flow is seen inside transverse sinuses (arrows). (C) Hyperintense lesions in the occipital region. (D) Normal cerebral MR image. 
venograms obtained at that moment of observation. (Figure 1b, arrows). During her monitorization, her cardiac apex beats per minute rised to $236 \mathrm{bpm}$ which necessitated electrocardiographic (ECG) examination which was evaluated as supraventricular tachycardia. Adenosin at a dose of $0.05 \mathrm{mg} / \mathrm{kg}$ was administered, however heart rhythm did not normalize which necessitated a second dose with resultant normalization of the rhythm. Blood pressure remained at high levels (ABP, 145/110 $\mathrm{mmHg}$ ), so antihypertensive treatment (amlodipine $5 \mathrm{mg} / \mathrm{g}$, and metoprolol $1 \mathrm{mg} / \mathrm{kg} / \mathrm{g}$, oral) was initiated. Cranial MRI demonstrated bilateral, and symmetrical subcortical hyperintense lesions in occipital areas on T2-weighted, and flair images. Lesions were reported as unrelated to the metastases of the primary disease, but consistent with PRES (Figure 1c).

During monitorization of the patient, swelling on his left arm decreased in size, and serial Doppler US examinations revealed that thrombus remained in the same location but regressed The clinical status of the patient under antihypertensive treatment gradually improved, her blood pressure, and symptoms were kept under control. Control cranial MRI obtained three weeks later revealed disappearance of parenchymal lesions (Figure 1d). The patient is still under our follow-up protocol, and her chemotherapy still continues without any clinical complaints.

\section{DISCUSSION}

Among thrombogenic factors in children, activation of coagulation mediated by procoagulant substances, deterioration of the fibrinolytic pathways, chemotherapy, and relevant prothrombotic risk factors can be enumerated. In a study by Celkan et al. [7] as predisposing factors, most frequently malignancies, and infections were detected. In another study, central venous catheterization was the most frequently seen factor [8]. In our patient a thrombus formation was detected on the junction between cephalic, and subclavian veins, and priorly central venous catheter was thought to be potentially responsible for thrombus formation.

In children most frequently seen malignancy associated with thrombus formation is acute lymphoblastic leukemia (ALL), and thrombus has been detected in $5-40 \%$ of the cases with ALL. Bay et al. [9] detected thrombi in $1.1 \%$ of ALL patients. Still in another study, the authors indicated that in pediatric cases with diagnosis of acute lymphoblastic leukemia, during induction chemotherapy, and especially during or after L-asparaginase therapy, thrombotic events could be seen [3]. In the present case, we thought that L-asparaginase might be responsible for thrombus formation. In another study, deep vein thrombosis was detected in 2 out of 10 cases diagnosed as ALL, and in one patient presence of a central catheter was reported [10]. Therefore, in the light of all these results one can emphasize the potential role of $\mathrm{L}$-asparaginase in thrombus formation in patients with ALL.

In the diagnosis of deep vein thrombosis, as one of the noninvasive, cost-effective, easily applicable imaging modalities, color-Doppler US has been used. Doppler US report of our case indicated presence of a thrombus on the junction of the left cephalic, and subclavian veins. In a study sensitivity, and specificity of color Doppler US was reported as 77.8 , and $100 \%$ in the detection of both proximal, and distal vein thrombosis (DVT), respectively. Accordingly the authors stressed the importance of color Doppler US for the initial diagnosis of DVT [11].

Cerebral venous thrombosis can manifest itself with infection, dehydration, renal failure, trauma, malignancy, hematological disorders together with many risk factors. Our patient suffered from convulsive episodes which necessitated cranial MRI venography with the indication of suspect dural sinus thrombus. On cranial MRI venograms blood flow was not observed within the left transverse sinus. In another study, on cranial MR venograms, in a total of 16 patients, thrombi in only one $(n=11 ; 68.8 \%)$ or multiple venous sinuses $(n=5 ; 31.3 \%)$ were demonstrated [12]. However, interestingly in our case, diffusion MRI revealed presence of blood flow in transverse sinuses, and contrast agent was not seen momentarily on venograms which indicated lack of any thrombi. Management of venous thrombus involves anticoagulant, anticonvulsant, and supportive treatments. Besides, use of LMWH for ALL patients under L-asparaginase therapy is effective, and safe in the prevention of thromboembolism. Çalık et al. [13] used LMWH for the treatment of deep vein thrombosis with excellent response rates. We 
also observed regression of thrombi with LMWH therapy.

Though pathophysiology of PRES has not been elucidated yet, currently, higher blood pressure, and arterial edema due to cerebral hyperperfusion secondary to impairment of cerebral autoregulation has been held responsible [2]. In a study, hypertension was indicated as the culprit etiological factor, in our case, hypertension which developed suddenly, but could be brought under control with treatment was observed. Clinically, convulsive episodes have been reported in cases with PRES secondary to brain edema. Only one of 2 cases with diagnosis of PRES, convulsions were reported in a study [14]. Similarly, we also observed tonic-clonic convulsions in our patient.

In PRES bilateral, and asymmetrical homogenous brain edema is detected in parietooccipital white matter on MRI, while asymmetrical locations have been also reported In 8 cases diagnosed as PRES, signal abnormalities were observed on the posterior, while in seven cases with PRES, on anterior circulatory structures [15]. Symmetrical, and bilateral hyperintense lesions were detected in the occipital regions which were reported to be consistent with PRES.

In conclusion, we presented our case with diagnosis of PRES established by clinical, and radiological methods, and aimed to emphasize that in patients with sudden changes in the state of consciousness during chemotherapy, this syndrome which regresses completely with symptomatic treatment should be thought in the early stage of differential diagnosis.

Informed Consent: Written informed consent was obtained from the patient who participated in this study.

Conflict of Interest: No conflict of interest was declared by the authors.

Financial Disclosure: The authors declared that this study has received no financial support.

\section{REFERENCES}

1. Tekşam M, Casey SO, Michel E, Truwit CL. Posterior reversibl ensefalopati sendromu: patofizyoloji ve ileri MRG teknikleri ile korelasyon. Tanısal ve Girişimsel Radyoloji Dergisi 2001;7:46472.

2. Bartynski WS. Posterior reversible encephalopathy syndrome, part 2: controversies surrounding pathophysiology of vasogenic edema. AJNR Am J Neuroradiol 2008;29:1043-9. CrossRef

3. Caruso V, Iacoviello L, Di Castelnuovo A, Storti S, Mariani G, de Gaetano G, et al. Thrombotic complications in childhood acute lymphoblastic leukemia: a meta-analysis of 17 prospective studies comprising 1752 pediatric patients. Blood 2006;108:221622. CrossRef

4. Athale UH, Chan AK. Thrombosis in children with acute lymphoblastic leukemia: part I. Epidemiology of thrombosis in children with acute lymphoblastic leukemia. Thromb Res 2003;111:125-31. CrossRef

5. Demirtaş O, Gelal F, Vidinli BD, Demirtaş LO, Uluç E, Baloğlu A. Cranial MR imaging with clinical correlation in preeclampsia and eclampsia. Diagn Interv Radiol 2005;11:189-94.

6. Sharma A, Whitesell RT, Moran KJ. Imaging pattern of intracranial hemorrhage in the setting of posterior reversible encephalopathy syndrome. Neuroradiology 2010;52:855-63. CrossRef

7. Celkan T, Apak H, Özkan A, Güven V, Erkan T, Çokuğraş FÇ, ve ark. Hastanede yatan çocuklarda saptanan tromboz etiyolojisi. Türk Pediatri Arşivi 2004;39:65-70.

8. Andrew M, David M, Adams M, Ali K, Anderson R, Barnard D, et al. Venous thromboembolic complications (VTE) in children: first analyses of the Canadian Registry of VTE. Blood 1994;83:1251-7.

9. Bay A, Öner AF, Cesur Y, Demir C, Mukul Y, Açıkgöz M. Çocukluk çağı akut lenfoblastik lösemi olgularında L-asparajinaźa bağlı toksisite. Van Tip Dergisi 2005;12:149-52.

10. Ranta S, Heyman MM, Jahnukainen K, Taskinen M, SaarinenPihkala UM, Frisk T, et al. Antithrombin deficiency after prolonged asparaginase treatment in children with acute lymphoblastic leukemia. Blood Coagul Fibrinolysis 2013;24:749-56.

11. Tiryaki Ş, Eğilmez H, Işık AO, Öztoprak İ, Arslan M. Alt ekstremite derin ven trombozu tanısinda renkli Doppler ultrasonografi. C. Ü. Tip Fakültesi Dergisi 2000;22:131-6.

12. Şenol MG, Toğrol E, Kaşıkçı T, Tekeli H, Özdağ F, Saraçoğlu M. Serebral Venöz Tromboz: 16 Olgunun İncelenmesi. Düzce Tip Fakültesi Dergisi 2009;11:32-7.

13. Çalık M, Pişkin İE, Üstündağ G, Kardeş H. Derin ven trombozu ile başvuran bir akut miyeloid lösemi olgusu. Klinik ve Deneysel Arastırmalar Dergisi 2011;2:114-7.

14. Akgün N, Karaman M, Başyiğit S, Yılmaz H, Özcan AA. Posterior reversbl ensefalopati: 2 olgu sunumu. İstanbul Tip Dergisi 2010;2:82-5.

15. Bartynski WS, Boardman JF. Catheter angiography, MR angiography, and MR perfusion in posterior reversible encephalopathy syndrome. AJNR Am J Neuroradiol 2008;29:447-55. CrossRef 